\title{
PELAKSANAAN PENDIDIKAN INKLUSIF UNTUK SISWA DENGAN HAMBATAN PENGLIHATAN (LOW VISION) DI SEKOLAH DASAR
}

\author{
Innayatul Khaeroh, \\ Pendidikan Khusus, Fakultas Ilmu Pendidikan, Universitas Negeri Jakarta \\ innayakhaeroh@gmail.com, \\ Fela Advelia, Abdul Rosyid, Asep Supena \\ Pendidikan Khusus, Fakultas Ilmu Pendidikan, Universitas Negeri Jakarta \\ fela.advelia@gmail.com,ocitbyocit@gmail.com,supena2007@yahoo.com
}

\begin{abstract}
Abstrak
Penelitian ini bertujuan untuk mendeskipsikan pengalaman sukses guru dalam melaksanakan pendidikan untuk siswa dengan hambatan penglihatan (low vision) di sekolah inklusif. Penelitian ini menggunakan pendekatan kualitatif dengan metode naratif inquiri. Penelitian ini dilaksanakan di salah satu sekolah dasar umum di DKI Jakarta yang memiliki satu siswa dengan hambatan penglihatan (low vision). Pengumpulan data dilakukan melalui wawancara mendalam kepada guru pendidikan khusus (GPK) yang telah bekerja di sekolah tersebut selama 15 tahun. Ada tiga fokus utama yang diteliti, yaitu pengelolaan pembelajaran di kelas, penggunaan media pembelajaran, dan penilaian hasil belajar. Hasil penelitian menunjukkan bahwa pelaksanaan pendidikan inklusif untuk siswa low vision sudah cukup baik, baik dari segi media pembelajaran, proses kegiatan belajar mengajar, cara pemberian materi dari guru kepada siswa, dan evaluasi pembelajaran yang dilakukan.
\end{abstract}

Kata Kunci : pendidikan inklusif, low vision

\begin{abstract}
This study aims to describe the successful experiences of teachers in implementing education for students with low vision in inclusive schools. This study uses a qualitative approach with a narrative inquiry method. This study was conducted at one of the public elementary schools in DKI Jakarta which has one student with low vision. Data collection was carried out through in-depth interviews with special education teachers / guru pendamping khusus (GPK) who had worked at the school for 15 years. There are three main focuses that are studied, namely the management of learning in the classroom, the use of instructional media, and the assessment of learning outcomes. The results showed that the implementation of inclusive education for low vision students was good enough, in terms of instructional media, the process of teaching and learning activities, how to provide material from teachers to students, and evaluation of learning conducted.
\end{abstract}

Keywords : inclusive education, low vision 


\section{PENDAHULUAN}

Pada awal masa pendidikan, satu-satunya sumber ilmu yang tersedia untuk memperoleh pelajaran pada saat itu adalah tenaga pengajar atau guru yang berkompeten dan memiliki pengalaman. Seiring berkembangnya zaman, sumber belajar pun turut mengikuti perkembangan dengan adanya buku. Johan Amos Comenius menulis sebuah buku yang berjudul Orbis Sensualium Pictus (Dunia Tergambar) yang mana tercatat sebagai buku bergambar pertama yang ditujukan untuk anak sekolah pada tahun 1657. Kehadiran buku tersebut sebagai media membantu menyadarkan para tenaga pendidik lainnya bahwa dalam memberikan pengalaman belajar yang maksimal, sangat perlu untuk melibatkan seluruh indera yang berfungsi termasuk penglihatan dan pendengaran.

Kata media sendiri sebenarnya berasal dari bahasa Latin yaitu "medio" atau "medium” yang memiliki arti sebagai perantara atau pengantar. Secara khusus, kata media dapat memiliki arti sebagai alat komunikasi yang dapat digunakan untuk memberikan informasi dari sebuah sumber dan disampaikan kepada penerima (Bahri Djamarah dkk, 2006: 13). Pada umumnya, media pembelajaran yang dipakai oleh guru di sekolah sangatlah berpengaruh pada proses perkembangan akademik maupun non akademik siswa. Pengaruh tersebut tidak hanya berefek pada siswa yang tampak normal secara fisik saja, tetapi berefek juga pada siswa dengan hambatan fisik seperti siswa yang mengalami hambatan dalam penglihatan atau biasa disebut dengan tunanetra.

Dalam segi bahasa, kata tunanetra terdiri dari kata "tuna” dan "netra". Dalam KBBI kata tuna berarti tidak memiliki, tidak punya, luka atau rusak. Sedangkan kata netra berarti penglihatan. Dengan demikian tunanetra berarti seseorang yang rusak penglihatannya. Tunanetra adalah keadaan di mana seseorang mengalami gangguan atau hambatan pada indera penglihatannya, sekalipun ia menggunakan kacamata atau alat bantu, namun jika sudah parah maka tidak mampu difungsikan lagi indera penglihatannya. Gangguan tersebut mengakibatkan mereka kesulitan untuk melakukan aktivitas sehari-hari, terutama belajar. Walaupun dengan keadaan yang demikian, intelegensi yang dimiliki oleh seorang tunanetra sama saja dengan orang-orang pada umumnya.

Pada dasarnya, tunanetra dibagi menjadi dua kelompok, yaitu buta total (blind) dan kurang penglihatan (low vision). Dikatakan blind bila tidak dapat melihat dua jari di mukanya atau hanya melihat sinar atau cahaya yang lumayan dapat dipergunakan untuk orientasi mobilitas. Mereka tidak bisa menggunakan huruf lain selain huruf braille. Sedangkan yang disebut low vision adalah mereka yang bila melihat sesuatu, mata harus didekatkan, atau mata harus dijauhkan dari objek yang dilihatnya, atau mereka yang memiliki pemandangan kabur ketika melihat objek. Untuk mengatasi permasalahan penglihatan, para penderita low vision ini menggunakan kacamata atau lensa. 
Dalam proses kegiatan pembelajaran, seorang tunanetra akan mengalami kendala sesuai dengan tingkat ketunanetraannya. Seseorang yang mengalami buta total (blind) akan membutuhkan lebih banyak bantuan jika dibandingkan dengan yang mengalami low vision (kurang penglihatan). Untuk melakukan proses KBM bagi siswa tunanetra, tentu membutuhkan media pembelajaran yang tepat agar pembelajaran dapat berjalan lancar, efektif, dan efisien. Terlepas dari tingkat ketunanetraan yang dimiliki oleh mereka, perlu tersedianya media pembelajaran dan fasilitas khusus untuk tunanetra di sekolah, baik sekolah segregasi maupun sekolah inklusi, sehingga memudahkan mereka untuk menerima pelajaran yang diberikan oleh guru.

Pendidikan segregasi merupakan pendidikan paling kuno yang sistem pelaksanaannya secara terpisah untuk menumbuhkembangkan potensi peserta didik luar biasa baik yang menyandang ketunaan atau kecerdasan unggul secara optimal agar nantinya dapat bermanfaat bagi diri sendiri, keluarga, dan masyarakat. Contoh dari pendidikan segregasi adalah sekolah-sekolah luar biasa (SLB) yang ada di Indonesia.

Pendidikan inklusi adalah pendidikan yang mengakomodasikan semua anak tanpa memandang kondisi pada anak seperti kondisi fisik, mental intelektual, emosional, sosial, maupun kondisi lainnya. Pendidikan yang memungkinkan anak mendapatkan layanan pendidikan di sekolah-sekolah terdekat, kelas regular bersama-sama teman seusianya agar dapat mengembangkan potensi-potensi yang dimilikinya secara optimal. Ada banyak contoh sekolah-sekolah penyelenggara inklusi di Indonesia, salah satunya adalah SD Meruya selatan 06 Pagi yang terletak di DKI Jakarta.

SD Meruya Selatan 06 Pagi adalah salah satu sekolah dasar di DKI Jakarta yang kini memiliki status sebagai sekolah inklusi. Sekolah tersebut menerima lebih dari satu kekhususan untuk belajar bersama-sama dengan siswa pada umumnya di kelas reguler. SD Meruya Selatan 06 Pagi saat ini memiliki siswa dengan kekhususan autisme, tunadaksa, tunarungu, hambatan wicara, tunagrahita, kesulitan belajar, hiperaktif, hambatan emosi dan perilaku, dan tunanetra.

Saat sudah mulai memasuki kegiatan proses belajar mengajar, tentunya perlu diperhatikan terkait bagaimana cara memberikan sebuah pemahaman mengenai materi yang akan disampaikan kepada anak berkebutuhan khusus tersebut. Siswa dengan kekhususan yang berbeda, pasti akan membutuhkan media pembelajaran yang berbeda pula untuk mempermudah mereka agar dapat memahami materi yang diberikan oleh guru. Oleh karena itu, pemerintah DKI Jakarta memberikan bantuan berupa media pembelajaran kepada sekolah dalam rangka memenuhi kebutuhan SD Meruya Selatan 06 Pagi dalam memfasilitasi siswa berkebutuhan khusus yang ada di sekolah tersebut. 
Namun, ada beberapa pertanyaan yang menjadi masalah bagi peneliti untuk akhirnya perlu dikaji. Sebenarnya apakah sistem pendidikan inklusif yang diterapkan di SD Meruya Selatan 06 Pagi Jakarta sudah cukup baik bagi siswa berkebutuhan khusus yang ada di sekolah tersebut? Bagaimana proses kegiatan belajar mengajar yang dilakukan oleh sekolah sebagai penyelenggara pendidikan inklusif? Media apa saja yang digunakan dalam proses pembelajaran bagi siswa low vision? Dan bagaimana proses evaluasi pembelajarannya?

\section{METODE}

Penelitian ini mengunakan pendekatan kualitatif dengan metode naratif inquiri, dikarenakan ada beberapa pertimbangan di antaranya adalah penelitian ini bersifat menggambarkan, menguraikan suatu hal dengan apa adanya, maksudnya adalah data yang dikumpulkan berupa katakata atau penalaran dan gambar, bukan berupa angka-angka. Teknik pengumpulan data dilakukan melalui wawancara dan studi dokumentasi. Wawancara dilakukan secara online dengan salah satu guru SD Meruya Selatan 06 Pagi Jakarta yaitu guru pendamping khusus (GPK) sebagai narasumber yang terpercaya, beliau sudah hampir 15 Tahun mengajar sehingga banyak pengalaman dan sukaduka yang sudah dirasakan saat mengajar di sekolah inklusif. Wawancara dilakukan dengan berpedoman pada instrument wawancara. Wawancara dilakukan selama 3 kali pertemuan. Pada pertemuan pertama membahas mengenai sistem pendidikan inklusif di Indonesia secara umum, pertemuan kedua membahas mengenai sistem pendidikan inklusif di SD Meruya Selatan 06 Pagi Jakarta, dan pertemuan ketiga membahas mengenai siswa dengan hambatan penglihatan low vision yang ada di SD Meruya Selatan 06 Pagi Jakarta. Studi dokumentasi berupa photo yang dilakukan setiap kegiatan wawancara berlangsung. Penelitian ini berkolaborasi dengan guru pendamping khusus (GPK) dan peneliti sebagai pelaksana. Penelitian ini dilaksanakan pada akhir bulan April 2020 sampai dengan awal bulan Juni 2020 melalui WhatsApp group untuk pertemuan pertama dan kedua, serta aplikasi zoom untuk pertemuan ketiga, dengan masing-masing kapasitas waktu selama satu jam.

\section{HASIL DAN PEMBAHASAN}

\section{HASIL}

Sekolah penyelenggara inklusif di DKI Jakarta kini sudah tidak asing lagi dikarenakan anjuran dari pemerintah untuk setiap sekolah regular menerima anak berkebutuhan khusus sebagai bagian dari siswanya. Salah satu sekolah penyelenggara inklusif di DKI Jakarta adalah SD Meruya selatan 06 Pagi. Sekolah tersebut terletak di Komplek Kebon Jeruk Jl. Lap Jabek RT 02 RW 01, Meruya Sel, Kec. Kembangan, Kota Jakarta Barat, DKI Jakarta 11650. SD Meruya Selatan 06 Pagi menjadi sekolah penyelenggara inklusif sejak pada tahun 2005. 
Dalam sistem pendidikan yang diterapkan di sekolah, Kurikulum 2013 tetap menjadi acuan atau panduan utama untuk menjalankan proses kegiatan belajar mengajar. Hanya saja, untuk anakanak berkebutuhan khusus, terdapat beberapa modifikasi tujuan yang ingin dicapai oleh sekolah dengan menyesesuaikan pada kemampuan masing-masing siswa. Dalam melakukan proses memodifikasi tersebut, seluruh guru ikut terlibat untuk menentukan modifikasi seperti apa yang memang dibutuhkan oleh setiap siswa, baik tunanetra, tunadaksa, autisme, tunagrahita, tunarungu, hambatan wicara, hiperaktif, dan kesulitan belajar.

Terdapat 35 orang siswa dengan berkebutuhan khusus di SD Meruya selatan 06 Pagi Jakarta yang tersebar di 13 rombel di sekolah. Adapun siswa dengan hambatan penglihatan (low vision) di SD Meruya Selatan 06 Pagi Jakarta berjumlah 1 orang bernama Peter (nama disamarkan) pada jenjang usia sekolah tingkat tinggi yaitu kelas 6. Peter mengalami ketidak-mampuan dalam melihat dikarenakan akibat dari kecelakaan, yaitu tertusuk oleh besi pada bagian belakang kepala dan mengenai syaraf bagian mata, sehingga membuat kerusakan pada matanya. Kondisi mata Peter hanya dapat melihat huruf yang berada di depan matanya saja dan dibantu dengan menggunakan huruf yang dibesarkan ukurannya. Ketidak-mampuannya dalam melihat membuat Peter memiliki sikap yang yang kurang percaya diri dan selalu merasa menjadi bahan perbincangan orang lain dalam hal yang negatif seperti membully kondisi fisiknya, sehingga membuat Peter kurang berinteraksi dengan orang lain dan sulit untuk diajak komunikasi dua arah.

Adapun sumber-sumber atau pembelajaran yang digunakan berasal dari lingkungan sekitar, buku yang tersedia di sekolah, youtube/video, dan internet. Kreatifitas guru dalam menggunakan sumber-sumber tersebut dapat menciptakan suasana kelas yang dapat diterima oleh semua siswa dan membuat siswa lebih mudah memahami materi yang disampaikan. Dalam pemberian tugas, semua siswa akan mendapatkan tugas yang sama, baik tugas yang dikerjakan di sekolah maupun tugas yang dikerjakan di rumah, namun untuk siswa dengan berkebutuhan khusus itu sendiri, tetap disesuaikan kembali dengan porsinya. Seperti halnya dalam tugas kelompok, jika siswa dengan berkebutuhan khusus mampu menyalin maka tugasnya yakni menyalin, jika siswa dengan berkebutuhan khusus mampu menggambar maka tugasnya pun membantu kelompoknya untuk menggambar, tetap disesuaikan dengan kemampuan yang dimilikinya.

Sebagai salah satu siswa dengan berkebutuhan khusus yang ada di sekolah, Peter dapat mengikuti setiap kegiatan belajar mengajar dengan cukup baik, mengumpulkan tugas dengan tepat waktu, baik tugas individu maupun tugas kelompok. Untuk kegiatan belajar mengajar yang cenderung menggunakan visual sebagai fungsi yang dominan seperti hal nya membaca, Peter akan menggunakan media pembelajaran berupa alat bantu untuk low vision. Alat bantu yang disediakan 
oleh sekolah adalah alat optik berupa lup (kaca pembesar) dan digital handheld magnifier (kaca pembesar elektronik berupa tablet).

Pada awalnya, ketika Peter duduk di bangku usia SD tingkat rendah, Peter belajar membaca dengan menggunakan lup atau kaca pembesar, dikarenakan pada saat itu sekolah belum mendapat bantuan dari pemerintah untuk menambah fasilitas yang baru dan lebih berkualitas. Lup adalah alat yang berfungsi untuk memperbesar tulisan awas/biasa yang berukuran kecil, lup ini digunakan sebagai media untuk membaca bagi siswa low vision. Cara kerja lup yaitu dengan memfokuskan tulisan secara satu-persatu atau kalimat-perkalimat yang dirasa berukuran kecil dan ingin dibaca, kemudian dengan sendirinya tulisan tersebut akan menjadi besar. Hanya saja dengan penggunaan lup ini dikatakan tidak efektif karena harus mengatur sendiri jarak antara penempatan lup dan tulisan awas/biasa untuk menciptakan pembesaran tulisan yang tepat sehingga dapat dibaca dengan baik. Hal itu perlu dilakukan dengan memaju dan/atau mundurkan lup kearah tulisan awas/biasa, akibatnya membutuhkan fokus mata menjadi sangat ekstra sekali.

Seiring berjalannya waktu, dengan diterimanya pengajuan proposal oleh pemerintah dari sekolah, Digital Handheld Magnifier pun menjadi sebuah alat bantu baru yang ada di sekolah, dan kini alat bantu tersebut menjadi media pembelajaran yang utama bagi siswa low vision. Digital Handheld Magnifier merupakan sebuah alat elektronik yang berbentuk tablet dengan beberapa ukuran seperti 3 inci, 5 inci, 7 inci dan 8 inci. Digital Handheld Magnifier dilengkapi dengan fitur camera, tombol on/off, tombol (+) dan tombol (-). Cara kerja Digital Handheld Magnifier ini adalah dengan menekan terlebih dahulu tombol on untuk menyalakan dan mengaktifkannya, kemudian tekan tombol fitur camera yang berfungsi untuk memfokuskan tulisan awas/biasa berukuran kecil yang ingin dibaca, lalu setelah itu siswa hanya perlu membesarkan tulisan tersebut dengan menekan tombol $(+)$ untuk memperbesar. Jika dirasa tulisan menjadi terlalu besar, siswa dapat menekan tombol (-) untuk memperkecil ukuran tulisan. Tombol (+) dan (-) ini dapat digunakan oleh siswa dengan disesuaikan pada kondisi visus siswa itu sendiri. Ketika sudah selesai digunakan, tekan tombol off untuk mematikan kembali atau menonaktifkan media tersebut.

Digital Handheld Magnifier sangat membantu Peter dalam membaca tulisan awas/biasa, fungsi utama dalam hal membesarkan dan/atau mengecilkan ukuran tulisan awas/biasa agar dapat sesuai dengan kemampuan melihatnya sangatlah memudahkan Peter dalam membaca. Jika dibandingkan dengan media sebelumnya yang Peter pakai saat SD tingkat usia rendah, Digital Handheld Magnifier lebih banyak kelebihannya dan lebih membuat kegiatan proses belajar mengajar menjadi efektif, dikarenakan fokus mata Peter hanya kepada tulisan yang akan dibaca saja, sedangkan untuk mengatur ukuran tulisan bisa menggunakan tombol (+) dan (-) yang sudah tersedia. 
Selama penggunaan media bagi siswa dengan hambatan penglihatan (low vision) di sekolah. Terdapat satu media yang masih belum dipakai oleh sekolah, yaitu printer braille. Printer braille digunakan untuk mencetak buku-buku braille. Printer braille akan secara otomatis mencetak hurufhuruf abjad menjadi huruf-huruf braille dengan prinsip mirip dengan penulisan menggunakan reglet dan stylusnya. Printer braille berbeda dengan printer pada umumnya karena tidak menggunakan tinta melainkan menggunakan sebaris stylus. Penggunaan printer braille pada dasarnya mirip dengan penggunaan printer teks pada umumnya. Namun kertas yang dipakai lebih tebal dan tentunya lebih mahal. Dokumen sebelumnya telah disiapkan menggunakan perangkat Personal Computer yang kemudian dikirimkan datanya ke printer braille. Printer braille akan secara otomatis mencetak pola-pola braille pada kertas sesuai dengan abjad yang telah dibuat. Printer braille ini masih belum dipakai oleh sekolah dikarenakan dalam penggunaanya sedikit agak rumit, membutuhkan waktu yang lama jika akan digunakan untuk mencetak ketas ataupun buku braille, dan juga membutuhkan skill yang khusus.

Biasanya ketika sedang berlangsungnya proses kegiatan belajar mengajar di kelas, guru akan melakukan penataan kelas dalam jangka waktu yang sudah ditentukan. Penataan kelas di SD Meruya Selatan 06 Pagi Jakarta dibagi menjadi tiga, yaitu duduk berkelompok, duduk pada posisi tetap/tidak berubah, dan rolling atau berpindah secara teratur dan bertahap. Penataan kelas bagi siswa dengan berkebutuhan khusus akan disesuaikan kembali dengan kebutuhannya masingmasing. Terkhusus untuk Peter, guru menggunakan penataan kelas dengan duduk pada posisi tetap dan tidak berubah-ubah, yaitu Peter tetap duduk di bangku yang berada tepat di depan papan tulis. Untuk siswa dengan hambatan penglihatan (low vision), sekolah menerapkan tipe Eye Centre, yaitu siswa hanya dapat melihat ke depan seolah-olah sedang memakai kacamata kuda. Hal itu dilakukan agar memudahkan siswa dalam proses membaca dan menyalin tulisan awas/biasa.

Evaluasi pembelajaran atau penilaian hasil belajar siswa dilakukan oleh guru kelas bersama dengan GPK selama satu semester sekali yang kemudian diinformasikan kembali kepada orang tua/wali siswa dalam bentuk raport. Pengisian nilai raport dilakukan dengan menggunakan acuan KKM (Kriteria Minimum Kelulusan). KKM bagi siswa pada umumnya dan siswa dengan berkebutuhan khusus tetaplah sama, hanya saja bagi siswa dengan berkebutuhan khusus terdapat makna yang menunjukkan perkembangan siswa. Pada saat pengambilan raport, guru pendamping khusus (GPK), guru kelas, dan orang tua/wali siswa akan mengadakan pertemuan langsung untuk membahas mengenai konsultasi anak, menentukan proses kegiatan belajar mengajar pada semester berikutnya, kira-kira apa saja yang akan dilakukan di semester berikutnya, sehingga ada kesepakatan antara orang tua/wali siswa dengan sekolah dalam menyusun sebuah program bagi $\mathrm{ABK}$, dikarenakan dengan orang tua/wali siswa mendukung program sekolah, maka akan lebih 
memudahkan sekolah begitupun dengan siswa berkebutuhan khusus untuk mencapai tujuan yang diinginkan.

\section{PEMBAHASAN}

Adapun dalam sistem pelaksaan pendidikan sebagai penyelenggara inklusif, SD Meruya Selatan 06 Pagi Jakarta tidak membeda-bedakan antara siswa berkebutuhan khusus dengan siswa pada umumnya, baik dari segi pemberian materi maupun pemberian tugas. Hanya saja memang dalam proses kegiatan belajar mengajarnya, banyak dilakukan modifikasi yang disesuaikan dengan kebutuhan setiap siswa. Untuk siswa dengan hambatan penglihatan (low vision), sekolah akan menggunakan media khusus yaitu lup (kaca pembesar) dan diginal handhled magnifier (kaca pembesar berupa tablet).

Media khusus yang digunakan oleh guru dalam proses kegiatan belajar mengajar bagi siswa dengan hambatan penglihatan (low vision) memang sudah cukup maksimal untuk melangsungkan pembelajaran yang lancar, efektif, dan efisien. Akan tetapi media pembelajaran tersebut tidak cukup untuk memberikan pemahaman yang luas terkait materi pembelajaran yang akan disampaikan oleh guru. Diperlukan berbagai variasi lagi agar media menjadi lebih beragam untuk semakin memudahkan siswa dengan hambatan penglihatan dalam melakukan kegiatan belajar mengajar sehari-hari, khususnya bagi siswa low vision. Hal itu sejalan dengan penelitian yang dilakukan oleh Irma Dewi Ramadani terkait dengan layanan pendidikan bagi siswa dengan hambatan penglihatan (low vision), Irma membahas mengenai sistem pembelajaran bagi siswa dengan hambatan penglihatan (low vision). Dalam penelitiannya, tertulis bahwa pembelajaran di dalam kelas bagi siswa dengan hambatan penglihatan (low vision) membutuhkan lebih banyak penyesuaian yang berbeda dari pada yang biasa diberikan kepada siswa pada umumnya.

Dalam penelitiannya juga, Irma menulis bahwa tidak hanya besar atau kecilnya huruf yang harus diperhatikan ketika pembelajaran, namun banyak hal lainnya yang juga perlu dipertimbangkan dalam memberikan pembelajaran untuk siswa dengan hambatan penglihatan (low vision). Beberapa contohnya adalah penggunaan objek nyata, tingkat cahaya atau penerangan, penggunaan warna yang menarik dan tidak selalu terpaku pada warna hitam, penyesuaian tempat pembelajaran, serta tinggi dan rendahnya suara. Menurutnya, semua aspek tersebut perlu diberikan dan menjadi pusat fokus ketika memberikan pengajaran kepada siswa dengan hambatan penglihatan (low vision).

Dalam proses kegiatan belajar mengajar di SD Meruya Selatan 06 Pagi Jakarta, siswa dengan hambatan penglihatan (low vision) sudah mendapatkan beberapa penyesuaian di dalam kelas. Contohnya guru memperhatikan penggunaan besar dan kecilnya huruf, guru juga memperhatikan bagaimana penataan kelas yang tepat bagi siswa dengan hambatan penglihatan (low vision) yaitu 
dengan menentukan posisi duduk sebagai tempat untuk melakukan kegiatan belajar mengajar di kelas di mana siswa dengan hambatan penglihatan (low vision) akan selalu duduk di barisan paling depan. Namun demikian, akan lebih menarik lagi jika guru memperhatikan penggunaan warna yang bervariasi agar membuat siswa dengan hambatan penglihatan (low vision) semakin merasa bahwa proses kegiatan belajar mengajar itu menyenangkan.

Pemberian media pembelajaran tentunya perlu disesuaikan juga dengan mata pelajaran apa yang sedang atau yang akan dipelajari oleh siswa dengan hambatan penglihatan (low vision) tersebut. Dikarenakan tidak semua media pembelajaran cocok untuk diberikan atau dapat digunakan ketika proses kegiatan belajar mengajar mata pelajaran tertentu. Menyesuaikan media pembelajaran dengan mata pelajaran sangat perlu dilakukan untuk memaksimalkan penggunaan media pembelajaran kepada siswa dengan hambatan penglihatan (low vision).

Kamal Lamichhane dalam penelitiannya mengenai mengajar siswa dengan hambatan penglihatan di lingkungan pendidikan inklusif juga menjelaskan bahwa penggunaan gaya mengajar yang tepat pada siswa dengan hambatan penglihatan (low vision), juga menjadi pertimbangan besar dalam memberikan pembelajaran kepada siswa dengan hambatan penglihatan (low vision) tersebut di sekolah inklusi dengan baik. Menerapkan ceramah sebagai gaya mengajar kepada siswa dengan hambatan penglihatan (low vision) tidak selamanya dapat memberikan hasil belajar yang efektif. Menurut Kamal, memberikan perhatian khusus dengan menerapkan gaya mengajar yang interaktif agar dapat meningkatkan partisipasi tingkat keaktifan siswa dengan hambatan penglihatan (low vision) adalah salah satu gaya mengajar yang tepat untuk diterapkan di dalam kelas.

Keadaan pembelajaran di SD Meruya Selatan 06 Pagi Jakarta sendiri sudah menerapkan gaya mengajar yang cukup baik kepada siswa dengan hambatan penglihatan (low vision) ketika di dalam kelas. Guru sudah memberikan perhatian khusus sebaik yang mereka bisa ketika proses kegiatan belajar mengajar sedang berlangsung. Siswa dengan hambatan penglihatan (low vision) diberikan tempat duduk di barisan paling depan agar lebih dekat dengan papan tulis sehingga dapat lebih mudah untuk membaca dan menyalin apa yang ada di papan tulis, guru juga selalu memeriksa keadaan siswa tersebut dan memastikan apakah ia memahami apa yang disampaikan oleh guru di kelas dan menanyakan apakah ia memiliki kesulitan tersendiri.

Tentunya, dengan memperhatikan aspek media pembelajaran dan juga bagaimana gaya mengajar yang tepat, dapat menjadi kunci dalam keberhasilan memberikan pendidikan kepada siswa dengan hambatan penglihatan (low vision) yang belajar di sekolah inklusif. SD Meruya Selatan 06 Pagi Jakarta sudah berhasil menerapkan kedua aspek tersebut meskipun masih belum maksimal secara keseluruhan. Namun demikian, diharapkan dengan terus berkembangnya dunia pendidikan di masa yang akan datang, guru-guru terutama yang bertugas di sekolah inklusi dapat 
memperhatikan aspek-aspek tersebut sebagai suatu pertimbangan memberikan pembelajaran yang tepat kepada siswa dengan hambatan penglihatan, khususnya siswa low vision.

\section{KESIMPULAN DAN SARAN \\ KESIMPULAN}

Pembelajaran bagi siswa dengan hambatan penglihatan low vision sama hal nya dengan siswa pada umumnya. Hanya saja dalam proses pembelajarannya, siswa dengan low vision membutuhkan media khusus yang membantunya dalam membaca tulisan awas/biasa. Media pembelajaran yang digunakan di SD Meruya Selatan 06 Pagi sudah cukup baik dan memadai bagi siswa dengan hambatan penglihatan low vision. Lup (kaca pembesar) dan Digital Handhled Magnifier (kaca pembesar elektronik berupa tablet) sangat membantu siswa low vision dalam proses membaca. Di mana membaca merupakan salah satu langkah utama dalam mencari ilmu.

Adapun terdapat satu media khusus bagi siswa tunanetra yang tidak dipakai selama dalam proses kegiatan belajar mengajar, yaitu printer braille. Printer braille ini tidak digunakan untuk mencetak buku-buku bertuliskan braille, karena untuk siswa dengan low vision saat ini tidak diajarkan kompensatoris braiile. Peter masih dapat melihat dan membaca tulisan awas/biasa dalam ukuran yang cukup besar dan sesuai dengan tingkat ketunanetraannya.

\section{SARAN}

Saran dari peneliti terhadap Guru Pendamping Khusus (GPK) maupun guru kelas, dan juga pihak sekolah.Sebaiknya meskipun kondisi siswa mengalami low vision tetap/perlu diajarkan kompensatoris braille dan Orientasi Mobilitas, di samping agar alat yang sudah tersedia dapat terpakai optimal dan memperlambat kerusakan pada alat tersebut (printer braille) serta mencegah penambahan kerusakan pada penglihatan siswa, dikarenakan jika siswa terus dipaksakan untuk membaca menggunakan sisa penglihatan matanya, ada kemungkinan fungsi penglihatan pada matanya akan semakin menurun seiring berjalannya waktu. 


\section{DAFTAR PUSTAKA}

Amrina, Fathia Nurul. 2019. Studi Deskriptif: Pola Asuh Orang Tua Penyandang Tunanetra Berdasarkan Penyebab Tunanetra, Kondisi Tunanetra, Usia Pernikahan, dan Pendidikan Terakhir. Skripsi. Semarang: Universitas Negeri Semarang.

Baharun, Hasan \& Awwaliyah, Robiatul. 2018. Pendidikan Inklusi Bagi Anak Berkebutuhan Khusus dalam Perspektif Epistemologi Islam. Jurnal Program Studi PGMI. Vol 5 No 1, Maret.

Khairani, Mutia. 2016. Media Flashcard Braille Terhadap Kemampuan Membaca Permulaan Anak Tunanetra. Jurnal Pendidikan Khusus.

Kurniawan, Iwan. 2015. Implementasi Pendidikan bagi Siswa Tunanetra di Sekolah Dasar Inklusi. Jurnal Pendidikan Islam. Vol 4 No 8.

Lamichhane, Kamal. 2016. Teaching Students with Visual Impairment in An Inclusive Educational Setting: A Case from Nepal. International Journal of Iclusive Education. DOI: $10.1080 / 13603116.1184323$.

Ma'rufah, Asfif. 2014. Dampak Kompetensi Profesional Guru Terhadap Hasil Pembelajaran Pendidikan Agama Islam Siswa SMA Muhammadiyah 3 Gadung Surabaya Tahun Pelajaran 2013/2014. Surabaya: UIN Sunan Ampel Surabaya.

Netriwati \& Lena, Sri Mai. 2017. Media Pembelajaran Matematika. Bandar Lampung: Permata Net.

Ramadani, Irma Dewi. 2017. Layanan Pendidikan Bagi Siswa Tunanetra Low Vision Kelas V SD Muhammadiyah Bogor. Jurnal Pendidikan Guru Sekolah Dasar. Edisi 9 Tahun Ke-6.

Rohani. 2019. Media Pembelajaran. Medan: Universitas Islam Negeri Sumatera utara.

Saifullah, E.H., dkk. 2019. Sistem Elektronik untuk Refreshable Braille dengan Fitur Suara dan Integrasi dengan Android. Jurnal Teknik ITS. Vol 8 No 1.

Sidiq, Zulkifli. 2018. Pengoperasian Komputer Program JAWS (Job Acces With Speech) For Windows Oleh Peserta Didik Tunanetra. Jurnal JASSI_anakku. Vol 19 No 1.

Selfiany, Elsa., dkk. 2010. Pengaruh Penggunaan Alat Bantu Kertas Bergaris Tebal dan Meja Baca terhadap Kemampuan Menulis dan Membaca Siswa Low Vision. Jurnal JASSI_Anakku. Vol 9 No 2.

Triutari, Indah. 2014. Persepsi Mahasiswa Penyandang Disabilitas Tentang Sistem Pendidikan Segregasi dan Pendidikan Inklusi. Jurnal Ilmiah Pendidikan Khusus.

Utama, Nelly. 2015. Pembelajaran Al-Qur'an pada Peserta Didik Tunanetra di SMPLB Negeri Semarang Tahun Pelajaran 2014/2015. Skripsi. Semarang: Universitas Islam Negeri Walisongo. 